\title{
Hydrochemical study of groundwaters from Botucatu city, São Paulo State, Brazil
}

\author{
C. A. dos Santos \& D. M. Bonotto \\ Departamento de Petrologia e Metalogenia, \\ Instituto de Geociências e Ciências Exatas-UNESP, Brazil
}

\begin{abstract}
This investigation was carried out at Botucatu city, São Paulo State, Brazil, and involved the study of groundwaters utilized for domestic consumption and industrial purposes. Botucatu city is situated in the recharge area of Guarani Aquifer System (GAS) in which the variegated quartzitic sandstones accumulated by eolian processes under desertic conditions and named Botucatu Formation were firstly described there. Notwithstanding, the municipality is drained by two hydrographic basins (Tietê River-north; Pardo River- south), groundwater has been extensively used there, justifying this investigation. The study involved the hydrochemical and radiometric analysis of 13 groundwater samples collected from tube wells exploiting different formations of the Paraná sedimentary basin: Botucatu, Pirambóia, Serra Geral, Marília, Adamantina, and Santo Anastácio. The $\mathrm{pH}$, silica, major ions, gross alpha radioactivity, gross beta radioactivity and activity concentration of dissolved ${ }^{210} \mathrm{Po}$ and ${ }^{210} \mathrm{~Pb}$ were measured at LABIDRO-Isotopes and Hydrochemistry Laboratory, IGCEUNESP-Rio Claro, Brazil, and compared with guideline reference values for drinking water quality. The results of the hydrochemical analysis were compared with the 1469 Ordinance of the Brazilian Health Ministry. The Piper diagram permitted to classify hydrochemically the samples, whereas the radioactivity levels were compared with the WHO guideline reference values for checking if they were appropriate for human consumption in terms of the parameters analyzed.
\end{abstract}

Keywords: groundwater composition, hydrochemistry, radioactivity, polonium. 


\section{Introduction}

São Paulo State is located in southeastern Brazil, bordering Atlantic Ocean (southeast) and the states of Minas Gerais (northeast), Rio de Janeiro (east), Paraná (southwest), and Mato Grosso do Sul (west) (Fig. 1). The state itself is the most populous Brazilian state, comprising circa 40 million inhabitants distributed over 645 municipalities. It has the highest number of industries and economic production, reaching $31 \%$ of the Brazilian GDP-gross domestic product. Despite the vigorous industrial production that includes high technology goods, the state is also well developed in agriculture and cattle breeding.

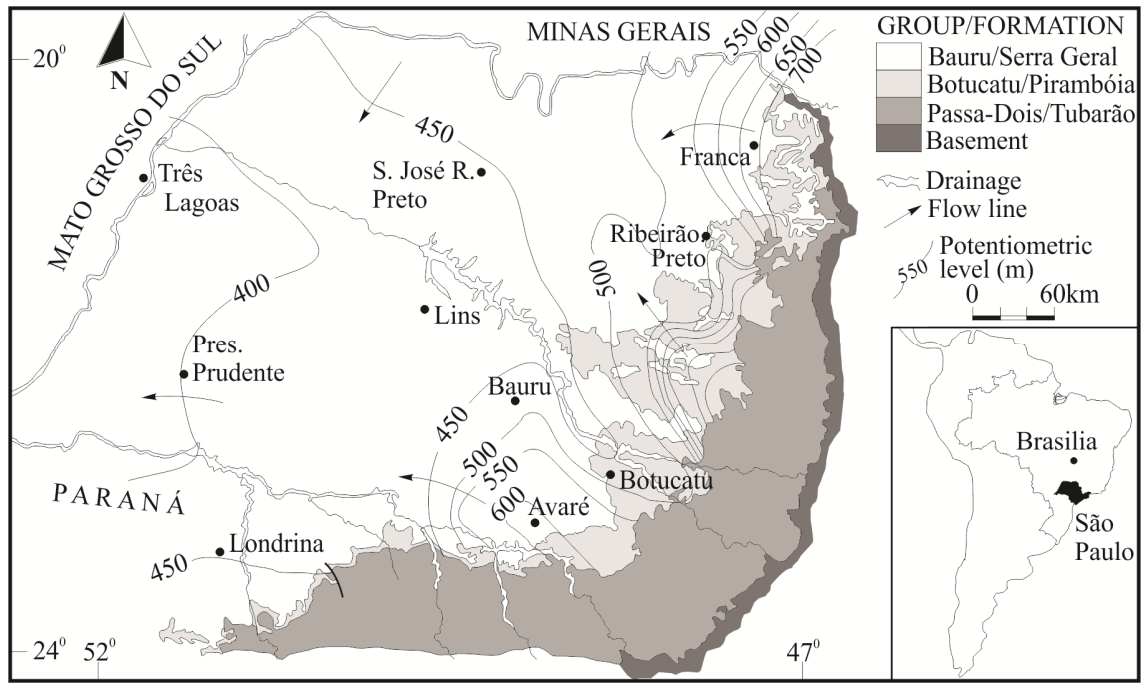

Figure 1: Location of Botucatu city in São Paulo State, Brazil, and groundwater flow direction in Guarani Aquifer System (GAS) (according to [1]).

This advanced stage of agricultural and industrial growth has implied on the need of using high amounts of water for all desired purposes, thus, the demand for groundwater in São Paulo State has drastically increased mainly in the last decade. It has been also expected a more accentuated increase in the next years, as a consequence of the technological advances of the sector coupled to the known advantageous of the groundwater in relation to superficial hydrological resources as, in principle, it is less subject do pollution.

Departamento de Águas e Energia Elétrica (DAEE) in São Paulo State developed the project "Study of groundwater in São Paulo State" between 1973 and 1982 with the aim of performing a systematic field investigation of the aquifer units, of the conditions of the groundwater exploitation and of its main purpose of use [2]. Eleven regional surveys were conducted along circa 18 months that included Botucatu city in Administrative Region No. 7, which 
comprised a total surface area of $63,000 \mathrm{~km}^{2}$ and a number of recorded tubular wells corresponding to about 1,750 .

\section{General features of the studied area}

Botucatu city (Fig. 1) is circa $30 \mathrm{~km}$ distant of Pirambóia municipality. The names of these cities are the same of the sandstones comprising the GASGuarani Aquifer System in São Paulo State as originally proposed in 1899 by the geologists of the São Paulo Geographical and Geological Commission [3]. The GAS overlies previous formations ranging from the igneous basement to the Paleozoic sediments of the Passa-Dois and Tubarão Groups, being covered by Cretaceous sediments of the Bauru-Caiuá formations (Fig. 1). The potentiometric surface of the water shows that about $70 \%$ of its total area has artesian conditions, and recharge occurs by direct infiltration of rainwater in the outcrop area, which is about $98,000 \mathrm{~km}^{2}$ [1]. The percolating water moves from the phreatic exposed areas that surround the entire basin (Fig. 1) towards its central part (Fig. 1).

The city of Botucatu is situated at $22^{\circ} 53^{\prime} 09^{\prime \prime} \mathrm{S}$ and $48^{\circ} 26^{\prime} 42^{\prime \prime} \mathrm{W}$, having an area of about $1483 \mathrm{~km}^{2}$ (Fig. 1). It is located at the northeastern edge of the Paraná sedimentary basin, cropping-out several stratigraphical units of the basin in the region, mainly the Pirambóia Formation (sandstones, shales and muddy sandstones), Botucatu Formation (sandstones and muddy sandstones), and Serra Geral Formation (basalts and diabases) [3].

The climate of the region is Aw type (Köeppen classification), i.e. tropical rainy weather characterized by wet summer (October through March) and dry winter (April through September). The mean annual rainfall corresponds to $1360 \mathrm{~mm}$. Botucatu possesses two distinct altitude levels, i.e. one varying from 400 to $500 \mathrm{~m}$ (lower level) and another between 700 and $900 \mathrm{~m}$ (higher level). This reflects on the mean annual temperature value that corresponds to $20.7^{\circ} \mathrm{C}$ (minimum $=15.3^{\circ} \mathrm{C}$; maximum $=26.1^{\circ} \mathrm{C}$ ).

Botucatu city is inserted into three Hydrographic Units for the Management of the Hydrological Resources (UGRHI): UGRHI 05 - located in the north extreme of the city, attached with Barra Bonita's dam; UGRHI 10 - covers almost half of the city (north part), between Barra Bonitas's dam and Serra Geral basaltic cuesta; UGRHI 17 - covers all of the south part of Botucatu city. The city is drained by two watersheds, i.e. Tietê River (north) and Pardo River (south), the last one belonging to the Paraná River basin.

\section{Concept of the study}

The groundwater study developed by DAEE in São Paulo State between 1973 and 1982 only took into account a very limited number of tubular wells drilled in Botucatu city as the water-supply system in the municipality was in that occasion mainly based on the use of surface waters. However, the population increase since the 1980s was accompanied by the development of agricultural and industrial activities, which caused an increment of the groundwater need. Thus, 
more wells were drilled for exploiting groundwater, but their hydrochemistry have been poorly known due to the limited number of parameters analyzed.

In this study, 13 groundwater samples were collected, whose geological substrate corresponded to Serra Geral, Santo Anastácio, Adamantina, Marília, Botucatu and Pirambóia formations. The samples were taken from deep wells drilled mainly for supplying water to the rural population. The water is chiefly used to domestic consumption and industrial purposes. Although this number of samples did not contemplate all wells drilled in the municipality, it provided helpful hydrogeochemical data for evaluating the groundwater quality there in order to face the requirements of the Brazilian agencies responsible by the water use and management.

Additionally, the database generated in this investigation also contributes to future guidelines for researches focusing the radioactivity as they were collected in different aquifer systems occurring in the city. The natural radionuclides are also a concern in drinking water as their activity concentrations in waters should not exceed the radiological standards established by the World Health Organization [4]. In the case of GAS in Brazil, some studies have been already realized focusing the natural radionuclides [5]. However, no relevant results have been reported for groundwaters from Botucatu city.

\section{Analytical methods}

The water samples $(\sim 20 \mathrm{~kg})$ for this study were stored in polyethylene bottles and, depending on the requirements of the analyzes, they were separated as unfiltered and unpreserved, filtered through $0.45 \mu \mathrm{m}$ membranes and preserved with different acids, etc. Several standard analytical techniques were utilized, for instance, methyl orange end-point titration, potentiometry, ion selective electrode, colorimetry, AAS-atomic absorption spectrometry, alpha spectrometry and gamma rays spectrometry.

A portable meter was used for in situ determination of $\mathrm{pH}$ by a digital meter coupled to a combination glass electrode. The alkalinity was measured by titration using a titrator with sulfuric acid standard solution to an end point evidenced by the color change of a standard indicator solution [6]. The obtained values corresponded to alkalinity due to the presence of bicarbonate, carbonate and/or hydroxides.

Calcium hardness (as $\left.\mathrm{CaCO}_{3}\right)$ and magnesium hardness $\left(\mathrm{as}_{\mathrm{MgCO}}\right)$ of the water samples were determined by the colorimetric method (wavelength $522 \mathrm{~nm}$ ) after chelating calcium with EGTA and calcium and magnesium with EDTA [6]. The analyses of dissolved sodium were done by AAS-atomic absorption spectrometry, whereas potassium was determined by the tetraphenylborate method that is based on the combination of $\mathrm{K}$ with sodium tetraphenylborate to form an insoluble white solid read at $650 \mathrm{~nm}$ by a program stored in Hach DR/2000 spectrophotometer. Nitrate, sulfate, chloride, and silica were also determined by colorimetry after adding other reagents for producing colored complexes [6]. 
The evaluation of the natural radioactivity in the groundwaters studied involved the quantification of the gross-alpha and gross-beta radioactivities, as well the ${ }^{210} \mathrm{Po}$ activity concentration. The method adopted for evaluating the gross alpha and beta radioactivities comprised a combined gamma-alpha spectrometry technique as reported by [7]. The gamma rays spectrometry was a non-destructive one that allowed the identification and quantification of $\beta$-emitters radionuclides, whereas the alpha spectrometry was based on the direct measurement of the $\alpha$-particles generated in the ${ }^{238} \mathrm{U}$ decay series. The $\gamma$-spectrometry was performed through a 3 " $\times 3$ " well-type $\mathrm{NaI}(\mathrm{Tl})$ scintillation detector, whereas the $\alpha$-counting was realized with four $0.1 \mathrm{~mm}$ depletion depth, $450 \mathrm{~mm}^{2}$ area, Passivated Implanted Planar Silicon (PIPS) detectors. The counting time was approximately 1 day for each distinct reading. The critical level of detection $\left(\mathrm{L}_{\mathrm{c}}\right)$ of both techniques has been estimated according to the procedure described by [8] that is widely used in nuclear spectroscopy. It corresponded to a number of counts of 834 , a count rate of $0.008 \mathrm{cps}$ and an activity of $30 \mathrm{mBq}$ for the gross beta measurements, whereas the activity ranged from 0.5 up to $3 \mathrm{mBq}$ (average $=1 \mathrm{mBq}$ ) for the gross alpha measurements [7].

The aliquots for ${ }^{210} \mathrm{Po}$ analysis were acidified to $\mathrm{pH} \cong 2$ with $8 \mathrm{M} \mathrm{HCl}$ and about $500 \mathrm{mg}$ of $\mathrm{FeCl}_{3}$ plus a known amount $(133.2 \mathrm{mBq})$ of ${ }^{209} \mathrm{Po}$ spike was added in order to assess ${ }^{210} \mathrm{Po}$ recovery. ${ }^{210} \mathrm{Po}$ was co-precipitated on $\mathrm{Fe}(\mathrm{OH})_{3}$ by increasing the $\mathrm{pH}$ to $7-8$ through addition of concentrated $\mathrm{NH}_{4} \mathrm{OH}$ solution. The precipitated was recovered and the $\mathrm{Fe}^{3+}$ added was extracted into an equal volume of isopropyl ether and polonium was plated onto a 1"-diameter $\mathrm{Cu}$ disc suspended in a hydroxylamine hydrochloride-sodium citrate solution heated to $85-90^{\circ} \mathrm{C}$ and stirred during 75-90 $\min$ [9]. The $\mathrm{Cu}$ disc was removed, washed with demineralized water, dried in a heating lamp and inserted in evacuated chambers for $\alpha$-counting with PIPS detectors. The isotope dilution technique was utilized to generate ${ }^{210} \mathrm{Po}$ activity concentration values from ${ }^{209} \mathrm{Po}$ and ${ }^{210} \mathrm{Po}$ peaks. Notwithstanding, [9] utilized $\mathrm{Ag}$ rather than $\mathrm{Cu}$ discs for Po-deposition, the

${ }^{210} \mathrm{Po}$ data were satisfactory, also allowing estimate the ${ }^{210} \mathrm{~Pb}$ activity concentration according to the procedure described by [10].

All data acquisition was performed at LABIDRO-Isotopes and Hydrochemistry Laboratory, IGCE-UNESP-Rio Claro, Brazil.

\section{Major hydrochemical data}

Table 1 reports the major hydrochemical data. The $\mathrm{pH}$ guideline value for potability is between 6.5 and 9.5, according to Ordinance 518 from the Brazilian Health Ministry. Four samples are not inserted in this interval. The limiting value established by WHO (World Health Organization) for sodium in potable waters is $200 \mathrm{mg} / \mathrm{L}$, which was not reached for any sample.

Potassium is found in low concentrations in natural waters because rocks containing this element are fairly resistant to weathering processes. All samples analyzed exhibited values below the potability standard of $10 \mathrm{mg} / \mathrm{L}$. 
Calcium in the groundwater varies, in general, from 10 to $100 \mathrm{mg} / \mathrm{L}$, and the values obtained in the samples are below $10 \mathrm{mg} / \mathrm{L}$. Magnesium in the groundwater generally ranges from 1 to $40 \mathrm{mg} / \mathrm{L}$, and no sample exceeded the lowest value.

Chloride is a contamination indicator for sewage and according to Ordinance 518 from the Brazilian Health Ministry, the guideline reference value is $250 \mathrm{mg} / \mathrm{L}$, which was not reached by any sample.

The maximum allowed limit for nitrate is $10 \mathrm{mg} / \mathrm{L}$, because superior values present health risk. The analyzed samples exhibited values below it. The highest levels were found for samples AAB and Banespa.

The Piper diagram [11] was used to plot the chemical data of each sample, as shown in Fig. 2. The samples AAB (A), Quinta do Manacás (B), 4 Irmãs Farm (D), SESI (H), São José Farm (I) and ITE (J) are classified as calcic bicarbonate; the samples Caio (C) and Staroup (K) are potassic; the samples BTC (E) and Banespa Farm (M) are bicarbonate and mixed in terms of dissolved cations; the sample Palmeiras Farm (F) is sodium bicarbonate; the sample São Paulo Farm $(\mathrm{G})$ is calcium chlorinated; the sample BTU-Pardinho (L) is chlorinated and mixed in terms of dissolved cations.

Table 1: Results obtained from the analyzed samples. Except $\mathrm{pH}$, all data are in $\mathrm{mg} / \mathrm{L}$. Neither $\mathrm{CO}_{3}{ }^{2-}$ nor $\mathrm{OH}^{-}$have been identified in the groundwater samples.

\begin{tabular}{ccccccccccc}
\hline Sample/CODE & $\mathrm{pH}$ & $\mathrm{Na}$ & $\mathrm{K}$ & $\mathrm{Ca}$ & $\mathrm{Mg}$ & $\mathrm{HCO}_{3}^{-}$ & $\mathrm{Cl}^{-}$ & $\mathrm{SO}_{4}{ }^{-2}$ & $\mathrm{NO}_{3}{ }^{-}$ & $\mathrm{SiO}_{2}$ \\
\hline Staroup/K & 6.62 & 2.4 & 3.97 & 3.27 & 0.3 & 44 & 24.5 & $<1$ & 2.4 & 34.4 \\
ITE/J & 6.53 & 0.5 & 0.75 & 4.17 & 0.54 & 28 & 9.5 & 1 & 3.5 & 23.8 \\
Caio/C & 7.03 & 2.1 & 4.09 & 3.39 & 0.23 & 42 & 5.7 & $<1$ & 2.4 & 19.4 \\
BTC/E & 7.18 & 3.8 & 1.07 & 3.51 & 0.34 & 44 & 9.6 & 3 & 3 & 17.6 \\
4 Irmãs Farm/D & 6.35 & 3.5 & 0.33 & 3.93 & 0.3 & 36 & 2.3 & 1 & 2.4 & 9.4 \\
São José Farm/I & 6.43 & 0.6 & 0.72 & 4.53 & 0.36 & 32 & 11.7 & 2 & 3.4 & 9.4 \\
AAB/A & 6.52 & 0.6 & 0.65 & 4.65 & 0.56 & 22 & 3.5 & 1 & 3.7 & 15.2 \\
SESI/H & 7.75 & 1.2 & 1.88 & 4.68 & 0.59 & 50 & 9.9 & $<1$ & 2.7 & 18.7 \\
São Paulo & 6.42 & 1.9 & 0.36 & 4.05 & 0.16 & 4 & 6.5 & 3 & 3.4 & 14.4 \\
$\begin{array}{c}\text { Farm/G } \\
\text { Palmeiras }\end{array}$ & 7.05 & 6.4 & 2.01 & 4.41 & 0.02 & 108 & 2.7 & 1 & 2.4 & 26.3 \\
$\begin{array}{c}\text { Farm/F } \\
\text { Quinta do }\end{array}$ & 7.12 & 1.6 & 0.95 & 4.47 & 0.73 & 150 & 1.8 & 1 & 0.6 & 6.8 \\
Manacás/B & & & & & & & & & 2.2 & 4.2 \\
$\quad$ BTU- & 4.79 & 0.8 & 2.85 & 3.18 & 0.94 & 2 & 1 & 1 & 2.2 \\
$\begin{array}{c}\text { Pardinho/L } \\
\text { Banespa }\end{array}$ & 6.54 & 1.8 & 1.09 & 3.21 & 0.94 & 108 & 5.4 & $<1$ & 3.7 & 18.6 \\
Farm/M & & & & & & & & & & \\
\hline
\end{tabular}




\section{Radioactivity analysis}

Tables 2 and 3 report the results of the analysis of the gross-alpha and gross-beta radioactivities. Different factors were used for the conversion of cps to $\mathrm{Bq} / \mathrm{L}$ for total gross alpha and beta activities. The factors corresponded to $3.609 \mathrm{cps} / \mathrm{Bq}$ and $3.784 \mathrm{cps} / \mathrm{Bq}$, respectively. These factors were determined from previous studies realized at LABIDRO.

The beta counting rate changed between 0.032 and $0.082 \mathrm{cps}$, and the total gross beta radioactivity between 0.121 and $0.310 \mathrm{~Bq} / \mathrm{L}$; the samples showed values below the limiting value indicated by $\mathrm{WHO}$ that is $1 \mathrm{~Bq} / \mathrm{L}$ (maximum). The alpha counting varied between 0.0010 and $0.0081 \mathrm{cps}$ and the total gross alpha activity ranged from 0.0038 to $0.0292 \mathrm{~Bq} / \mathrm{L}$, that are values below the WHO's limit of $0.5 \mathrm{~Bq} / \mathrm{L}$.

The spike (Po-209) activity added to each sample corresponded to $0.1332 \mathrm{~Bq}$. The ${ }^{210} \mathrm{Po}$ activity concentration was calculated from the relation between the counting rate of ${ }^{210} \mathrm{Po}$ and counting rate of ${ }^{209} \mathrm{Po}$ in the alpha spectrum obtained for each groundwater sample. The results are reported in Table 4. By calculating, it appears that the sample with the highest ${ }^{210} \mathrm{Po}$ activity concentration was BTUPardinho $(0.00205 \mathrm{~Bq} / \mathrm{L})$. The lowest activity concentration was found at Palmeiras Farm $(0.00038 \mathrm{~Bq} / \mathrm{L})$ which presented water catchment from Marília/Adamantina's formations. Most of the analyzed samples are used for human consumption and agriculture. The obtained results indicated that no sample exceeded the maximum value for Po-210 established by WHO $(0.2 \mathrm{~Bq} / \mathrm{L}=200 \mathrm{mBq} / \mathrm{L})$ (as shown in Table 4).

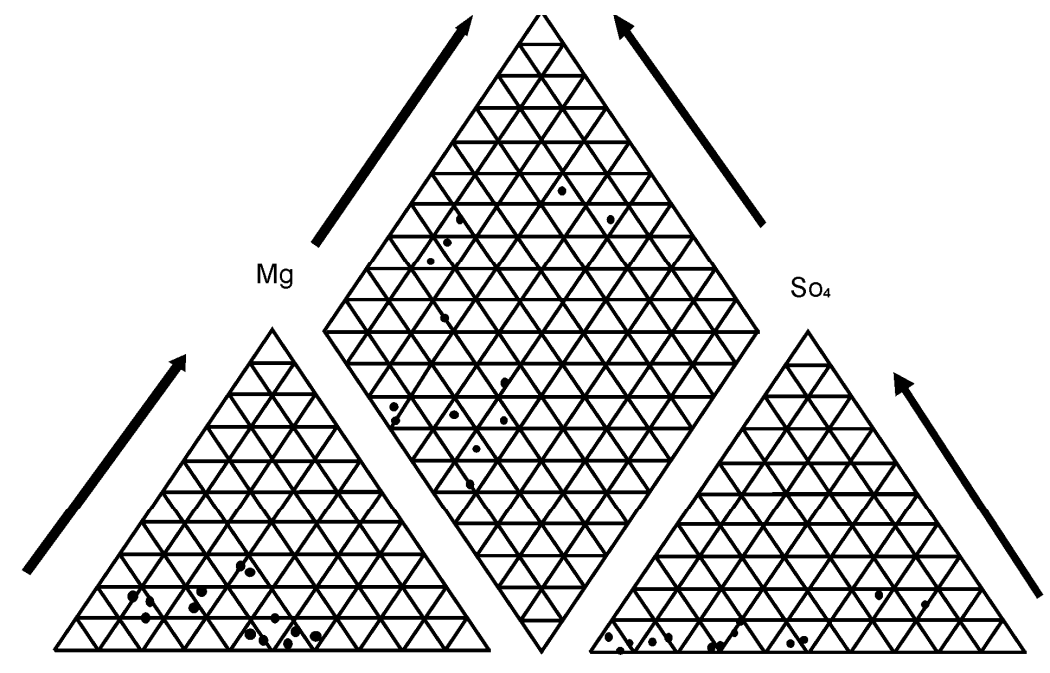

$\mathrm{Ca}$

$\mathrm{Na}+\mathrm{K}$

$\mathrm{HCO}_{3}+$

$\mathrm{Cl}$

$\mathrm{CO}_{3}$

Figure 2: Major chemical data of the groundwaters plotted on a Piper diagram. 
Table 2: Gross alpha radioactivity in the groundwater samples collected at Botucatu city, São Paulo State, Brazil.

\begin{tabular}{ccccc}
\hline CODE & Time $(\mathrm{s})$ & Counts & Counting Rate $(\mathrm{cps})$ & Activity $(\mathrm{Bq} / \mathrm{L})$ \\
\hline A & 90062.6 & 976 & 0.001 & 0.0038 \\
F & 89956.5 & 104 & $<\mathrm{Lc}$ & $<\mathrm{La}$ \\
C & 50712.6 & 56 & $<\mathrm{Lc}$ & $<\mathrm{La}$ \\
D & 59691.9 & 83 & $<\mathrm{Lc}$ & $<\mathrm{La}$ \\
G & 50713.5 & 428 & 0.0081 & 0.0292 \\
J & 82168.5 & 114 & $<\mathrm{Lc}$ & $<\mathrm{La}$ \\
B & 50712.8 & 111 & 0.0012 & 0.0043 \\
H & 89995.2 & 481 & 0.0050 & 0.0180 \\
L & 59722.5 & 401 & 0.0064 & 0.0231 \\
F & 59893.4 & 238 & 0.0037 & 0.0132 \\
I & 59918.6 & 376 & 0.0053 & 0.0191 \\
K & 90033.5 & 243 & 0.0017 & 0.0061 \\
\hline
\end{tabular}

Lc and La- detection limit, corresponding to $0.0003 \mathrm{cps}$ and $0.001 \mathrm{~Bq} / \mathrm{L}$, respectively; cps- counts per second.

Table 3: Gross beta radioactivity in the groundwater samples collected at Botucatu city, São Paulo State, Brazil.

\begin{tabular}{ccccc}
\hline CODE & Time $(\mathrm{s})$ & Counts & Counting Rate $(\mathrm{cps})$ & Activity $(\mathrm{Bq} / \mathrm{L})$ \\
\hline A & 82839 & 100321 & 0.041 & 0.155 \\
F & 86645 & 106770 & 0.062 & 0.235 \\
C & 84122 & 26103 & 0.040 & 0.151 \\
D & 50893 & 61692 & 0.042 & 0.159 \\
G & 91333 & 27103 & 0.039 & 0.148 \\
J & 73307 & 91765 & 0.082 & 0.310 \\
B & 82401 & 101514 & 0.062 & 0.235 \\
H & 74846 & 90625 & 0.041 & 0.155 \\
L & 42087 & 50583 & 0.032 & 0.121 \\
F & 87703 & 107566 & 0.056 & 0.212 \\
I & 86745 & 106820 & 0.061 & 0.231 \\
K & 59408 & 72297 & 0.047 & 0.178 \\
E & 91914 & 18103 & 0.040 & 0.151 \\
\hline
\end{tabular}

When a water sample is collected, it contains dissolved radionuclides, usually in radioactive disequilibria conditions. The initial ${ }^{210} \mathrm{Po}$ activity $\left(A_{P o i}\right)$ decreases according to the general equation of radioactive decay: $A_{P o}=A_{P o i} \exp \left(-\lambda_{1} t\right)$ where: $\lambda_{I}$ is the ${ }^{210} \mathrm{Po}$ decay constant $\left(0.005\right.$ days $\left.^{-1}\right)$, and $A_{P o}$ corresponds to the ${ }^{210} \mathrm{Po}$ activity at instant $t$. The ${ }^{210} \mathrm{~Pb}$ decay constant is low $\left(8.55 \times 10^{-5}\right.$ days $\left.^{-1}\right)$, and, consequently, its decrease under the usual time scale of laboratorial experiments is low, i.e. it decreases only $3 \%$ in one year, that is significantly lower than the ${ }^{210} \mathrm{Po}$ decrease $(84 \%)$. Under this aspect, significant modifications in the ${ }^{210} \mathrm{~Pb}$ activity concentration relatively to that of ${ }^{210} \mathrm{Po}$ are not expected to occur if water samples are analyzed within a time scale of several months after sampling. In practical terms, this is convenient because often it is not possible to 
analyze water samples for ${ }^{210} \mathrm{~Pb}$ and ${ }^{210} \mathrm{Po}$ immediately after collection and, consequently, they should remain stored in the laboratory for some time period.

Table 4: ${ }^{210} \mathrm{Po}$ activity concentration $\left(\mathrm{A}_{210}\right.$, in $\left.\mathrm{Bq} / \mathrm{L}\right)$ in the groundwater samples collected at Botucatu city, São Paulo State, Brazil.

\begin{tabular}{|c|c|c|c|c|c|c|c|}
\hline CODE & Nuclide & $\begin{array}{l}\text { Counting } \\
\text { Time (s) }\end{array}$ & $\begin{array}{l}\text { Region } \\
\text { (channel) }\end{array}$ & $\begin{array}{l}\text { Total } \\
\text { Counts }\end{array}$ & $\begin{array}{l}\mathrm{A}_{209} \\
(\mathrm{~Bq})\end{array}$ & $\begin{array}{l}\mathrm{A}_{210} \\
(\mathrm{~Bq})\end{array}$ & $\mathrm{A}_{210}$ \\
\hline \multirow[t]{2}{*}{ K } & Po-209 & $264,850.2$ & $519-551$ & 1622 & 0.1332 & & \\
\hline & Po-210 & & $577-599$ & 141 & & 0.01158 & 0.00106 \\
\hline \multirow[t]{2}{*}{$\mathrm{J}$} & Po-209 & $264,883.7$ & $492-534$ & 687 & 0.1332 & & \\
\hline & Po-210 & & $553-579$ & 42 & & 0.00814 & 0.00076 \\
\hline \multirow[t]{2}{*}{$\mathrm{E}$} & Po-209 & $255,025.5$ & $499-585$ & 2328 & 0.1332 & & \\
\hline & Po-210 & & $602-650$ & 190 & & 0.01087 & 0.00094 \\
\hline \multirow[t]{2}{*}{$\mathrm{D}$} & Po-209 & $234,994.7$ & $522-582$ & 4051 & 0.1332 & & \\
\hline & Po-210 & & $610-630$ & 169 & & 0.00556 & 0.00054 \\
\hline \multirow[t]{2}{*}{ I } & Po-209 & $170,646.9$ & $521-555$ & 2029 & 0.1332 & & \\
\hline & Po-210 & & $584-606$ & 143 & & 0.00939 & 0.00093 \\
\hline \multirow[t]{2}{*}{$\mathrm{H}$} & Po-209 & $234,526.4$ & $480-538$ & 613 & 0.1332 & & \\
\hline & Po-210 & & $563-583$ & 45 & & 0.00978 & 0.00088 \\
\hline \multirow[t]{2}{*}{ G } & Po-209 & $424,837.8$ & $480-550$ & 313 & 0.1332 & & \\
\hline & Po-210 & & $558-601$ & 38 & & 0.01618 & 0.00162 \\
\hline \multirow[t]{2}{*}{ F } & Po-209 & $234,548.7$ & $513-559$ & 1468 & 0.1332 & & \\
\hline & Po-210 & & $588-604$ & 44 & & 0.00399 & 0.00038 \\
\hline \multirow[t]{2}{*}{ B } & Po-209 & $85,434.4$ & $534-578$ & 540 & 0.1332 & & \\
\hline & Po-210 & & $598-628$ & 31 & & 0.00764 & 0.00076 \\
\hline \multirow[t]{2}{*}{$\mathrm{L}$} & Po-209 & $85,380.5$ & $490-550$ & 192 & 0.1332 & & \\
\hline & Po-210 & & $571-601$ & 31 & & 0.0215 & 0.00205 \\
\hline \multirow[t]{2}{*}{ A } & Po-209 & $234,573.4$ & $530-582$ & 1497 & 0.1332 & & \\
\hline & Po-210 & & $608-632$ & 99 & & 0.0088 & 0.00083 \\
\hline \multirow[t]{2}{*}{$\mathrm{C}$} & Po-209 & $254,998.8$ & $501-553$ & 1511 & 0.1332 & & \\
\hline & Po-210 & & $577-603$ & 255 & & 0.0225 & 0.00195 \\
\hline \multirow[t]{2}{*}{ M } & Po-209 & $424,816.3$ & $488-549$ & 1627 & 0.1332 & & \\
\hline & Po-210 & & $558-592$ & 203 & & 0.00764 & 0.00076 \\
\hline
\end{tabular}

$\mathrm{A}_{209}$ and $\mathrm{A}_{210}$ are the ${ }^{209} \mathrm{Po}$ and ${ }^{210} \mathrm{Po}$ activities, respectively. 
If it is disregarded the initial ${ }^{210} \mathrm{Po}$ activity concentration $\left(A_{\text {Poi }}\right)$ in the groundwaters analyzed, then, the following simplified equation may be written:

$$
A_{P o}(t)=A_{P b}-A_{P b} \exp \left(-\lambda_{1} t\right)
$$

where: $A$ corresponds to the activity concentration of the respective radionuclide, $\lambda_{I}$ is the decay constant of ${ }^{210} \mathrm{Po}$, and $t$ is the time elapsed between the collection of the sample and the mid-counting date. In this way, this equation presents only one unknown, allowing estimate the initial ${ }^{210} \mathrm{~Pb}$ activity concentration from measured ${ }^{210} \mathrm{Po}$ activity concentration. Such simplified equation was applied to the whole dataset reported in Table 4 , yielding the estimate of the ${ }^{210} \mathrm{~Pb}$ activity concentration in the groundwater samples, as shown in Table 5.

Table 5: $\quad{ }^{210} \mathrm{Po}$ activity concentration $(\mathrm{Po}-210$, in $\mathrm{Bq} / \mathrm{L})$ and estimated ${ }^{210} \mathrm{~Pb}$ activity concentration $(\mathrm{Pb}-210$, in $\mathrm{Bq} / \mathrm{L})$.

\begin{tabular}{cccccc}
\hline CODE & T1 & T2 & Po-210 & Initial Po-210 & Pb-210 \\
\hline K & 0.014 & 81 & 0.00106 & 0.0175 & 0.00318 \\
J & 0.014 & 81 & 0.00076 & 0.0123 & 0.00228 \\
E & 0.014 & 31 & 0.00094 & 0.0130 & 0.00655 \\
D & 0.014 & 124 & 0.00054 & 0.0106 & 0.00117 \\
I & 0.014 & 51 & 0.00093 & 0.0122 & 0.00413 \\
H & 0.014 & 51 & 0.00088 & 0.0129 & 0.00391 \\
G & 0.014 & 124 & 0.00162 & 0.0316 & 0.00351 \\
F & 0.014 & 12 & 0.00038 & 0.0044 & 0.00653 \\
B & 0.014 & 33 & 0.00076 & 0.0093 & 0.00499 \\
L & 0.014 & 17 & 0.00205 & 0.0239 & 0.0251 \\
A & 0.014 & 33 & 0.00083 & 0.0107 & 0.00546 \\
C & 0.014 & 31 & 0.00195 & 0.0269 & 0.0136 \\
M & 0.014 & 47 & 0.00076 & 0.0103 & 0.00363 \\
\hline
\end{tabular}

T1 - time (in days) elapsed between the deposition end and counting beginning; $\mathrm{T} 2$ - time (in days) elapsed between the collection of the sample and the midcounting date.

\section{Conclusion}

This investigation was carried out at Botucatu municipality, São Paulo State, Brazil, and involved the study of groundwater utilized for domestic consumption and industrial purposes. Botucatu city is situated in the recharge area of Guarani aquifer, thus, the water quality must be assured for appropriate use and management of this important hydric resource. The study involved the hydrochemical and radiometric analysis of thirteen groundwater samples collected in a monitoring program held in 2010 and held in tube wells exploiting different formations of the Paraná sedimentary basin. The results of the hydrochemical analysis were compared with the 518 Ordinance of the Brazilian Health Ministry and all values obtained were below the maximum allowed. The Piper diagram permitted to classify six samples as bicarbonated calcic, two samples as bicarbonated potassic, two samples as bicarbonated and mixed in terms of dissolved cations, one sample as bicarbonated sodic, one sample as 
chlorinated calcic, and one sample as chlorinated and mixed in terms of dissolved cations. Despite this variable hydrochemical composition, all samples exhibited radioactivity levels below the maximum allowed by WHO that are: gross alpha radioactivity $=0.5 \mathrm{~Bq} / \mathrm{L}$; gross beta radioactivity $=1.0 \mathrm{~Bq} / \mathrm{L}$; ${ }^{210} \mathrm{Po}=0.2 \mathrm{~Bq} / \mathrm{L}$; and ${ }^{210} \mathrm{~Pb}=0.1 \mathrm{~Bq} / \mathrm{L}$. Thus, the waters were appropriate for human consumption in terms of the analyzed parameters in that sampling campaign, which was the first detailed hydrochemical study developed there. The acquired database is relevant for the development of further systematic surveys since the seasonal and anthropogenic effects, among others, can modify the groundwater quality as widely recognized elsewhere. In Brazil, there is no tradition on conducting long-term hydrochemical monitoring programs and this is a particular challenge in the study area due to its special location in the recharge area of the giant transboundary Guarani Aquifer System.

\section{References}

[1] Silva, R.B.G., Estudo hidroquímico e isotópico das águas subterrâneas do aqüífero Botucatu no Estado de São Paulo. PhD Thesis, USP, São Paulo, 1983.

[2] Rocha, G., Mapa de Águas Subterrâneas do Estado de São Paulo - escala 1:1.000.000; DAEE (Departamento de Águas e Energia Elétrica), IG (Instituto Geológico), IPT (Instituto de Pesquisas Tecnológicas do Estado de São Paulo), CPRM (Serviço Geológico do Brasil), São Paulo, 2005.

[3] Almeida, F.F.M. \& Melo, M.S., A bacia do Paraná e o vulcanismo Mesozóico. Mapa geológico do estado de São Paulo, ed. IPT (Instituto de Pesquisas Tecnológicas do Estado de São Paulo), Promocet: São Paulo, v. 1, pp. 46-81, 1981.

[4] WHO (World Health Organization), Guidelines for drinking water quality, $4^{\text {th }}$ ed., WHO Press: Geneva, 2011.

[5] Bonotto, D.M. \& Bueno, T.O., The natural radioactivity in Guarani aquifer groundwater, Brazil. Appl. Radiat. Isot., 66, pp. 1507-1522, 2008.

[6] HACH, Water Analysis Handbook, $2^{\text {nd }}$ ed., Hach Company: Loveland, 1992.

[7] Bonotto, D.M., Bueno, T.O., Tessari, B.W. \& Silva, A., The natural radioactivity in water by gross alpha and beta measurements. Radiat. Meas., 44, pp. 92-101, 2009.

[8] Currie, L.A., Limits for qualitative and quantitative determination. Anal. Chem., 40, pp. 586-593, 1968.

[9] Flynn, W.W., The determination of low levels of polonium-210 in environmental materials. Anal. Chim. Acta, 43, pp. 221-227, 1968.

[10] Bonotto, D.M., Caprioglio, L., Bueno, T.O. \& Lazarindo, J.R., Dissolved ${ }^{210} \mathrm{Po}$ and ${ }^{210} \mathrm{~Pb}$ in Guarani aquifer groundwater, Brazil. Radiat. Meas., 44, pp. 311-324, 2009.

[11] Piper, A.M., A graphic procedure in the geochemical interpretation of water-analyses. Eos Trans. AGU, 25, pp. 914-928, 1944. 